\title{
STRATEGI PENGEMBANGAN PASAR DAERAH BERBASIS KOMODITAS UNGGULAN
}

\author{
Sulis Rochayatun ${ }^{1}$ \\ Email:soelieste13@gmail.com \\ Puji Handayati \\ Email:puji226@yahoo.com
}

\section{Ratna Dwi Nastiti ${ }^{3}$}

\begin{abstract}
Regional markets, including traditional markets that are now turned into people's markets, are certain areas where buyers and sellers meet, both directly and indirectly, through the process of buying and selling various types of consumer goods through bargaining which is also a market developed and managed by the regency government or city in Indonesia. People's market focal points can be observed from their influence on the fulfillment of small people's livelihoods. That is why the people's market is a pillar of people's economy. The purpose of this study is to formulate a strategy for developing regional markets in Pasuruan Regency to improve the community's economy based on regional superior commodities. This research is a field research using a descriptive quantitative approach. This research was conducted in 14 regional markets in the Pasuruan Regency administrative region and 5 village markets. The analysis shows that several factors are the strengths and weaknesses of traditional markets in Pasuruan Regency. The most prominent strength factor is that all of the markets sampled in this study are located in strategic locations. Whereas the most prominent weaknesses are lack of adequate sanitation (drainage is not functioning properly, bathroom, and toilet conditions, clean water is not all available, market disinfection has not been carried out, not yet free of vector / star of infectious diseases. Pasuruan Regency needs to revitalize traditional markets, namely physical renovations of market buildings, and accompanied by institutional building.
\end{abstract}

Keywords: traditional market, superior product

1 Corresponding author: Fakultas Ekonomi Universitas Negeri Malang

2,3 Fakultas Ekonomi Universitas Negeri Malang 


\section{PENDAHULUAN}

Pasar Daerah termasuk pasar tradisional di mana menurut Permendagri Nomor 37/M-DAG/PER/5/2017 yang sekarang berubah menjadi pasar rakyat adalah suatu area tertentu tempat bertemunya pembeli dan penjual, baik secara langsung maupun tidak langsung dengan proses jual beli berbagai jenis barang konsumsi melalui tawar menawar yang juga merupakan pasar yang dibangun dan dikelola oleh pemerintah daerah kabupaten atau kota di Indonesia. Istilah pasar rakyat digunakan untuk menunjukkan tempat berlangsungnya perdagangan oleh masyarakat setempat, sehingga mengandung ciri indigenous yang sudah berlangsung dalam waktu sangat lama. Focal point pasar rakyat dapat diamati dari pengaruhnya pada pemenuhan hajat hidup masyarakat kecil. Itulah sebabnya pasar rakyat merupakan pilar ekonomi kerakyatan.

Salah satu keunggulan pasar rakyat dibandingkan ritel modern adalah kehangatan interaksi dalam proses transaksinya. Konsumen mendapatkan pelayanan langsung yang hangat, akrab, dan humanis dari pedagang dalam proses tawar menawar yang seru. Di lapak-lapak pasar tradisional, fragmen semacam ini tersaji indah dalam ketulusan jiwa dan nuansa persaudaraan yang kental. Sebagian besar pelaku ekonomi di Pasar Rakyat adalah Usaha Mikro Kecil dan Menengah (UMKM). Eksistensi UMKM dalam menunjang perekonomian nasional telah terbukti. Fakta ini secara implisit merepresentasikan betapa pasar rakyat memiliki potensi besar sebagai agent of change khususnya pemberdayaan masyarakat.

Kabupaten Pasuruan secara administratif terdiri dari 24 kecamatan. Memiliki 7 sungai yang mengaliri wilayahnya, Kabupaten Pasuruan sangat kondusif untuk area pertanian tanaman pangan. Tak heran Kabupaten Pasuruan memiliki cukup banyak komoditas unggulan. Pasuruan dikenal sebagai sentra produksi padi. Selain padi, komoditas kentang juga salah satu hortikultura unggulan Kabupaten Pasuruan. Varietas yang dibudidayakan adalah varietas Granola, Granola Kembang, Atlantik, dan lain-lain. Jenis hortikultura sayuran lain yang dominan di Kabupaten Pasuruan adalah Kobis.

Kabupaten Pasuruan juga memiliki komoditas florikultura antara lain Bunga Krisan dan Bunga Sedap Malam. Hortikultura buah-buahan yang diunggulkan di Kabupaten Pasuruan adalah Buah Mangga dan Buah durian. Selain itu, komoditas unggulan perkebunan Kabupaten Pasuruan yang dibudidayakan dengan sistem agroforestry adalah kopi. Kabupaten Pasuruan saat ini juga memiliki sejumlah besar industri rumahan yang mulai muncul menawarkan beragam produk unggulan. Salah satu industri rumahan ini adalah industri kerajinan sulam benang dan industri kerajinan kayu.

Formasi sektor bisnis di Kabupaten Pasuruan baik sektor pertanian maupun industri merupakan potensi inflow bagi kegiatan perdagangan melalui pasar daerah. Apabila supply side di semua sektor ini dapat ditransaksikan di pasar daerah bisa dibayangkan betapa besar rantai nilai yang dapat diciptakan. Tak ketinggalan produk industri baik industri besar maupun industri kreatif rumahan turut diperdagangkan.

Tantangan saat ini adalah bagaimana membangun dan mengembangkan pasar rakyat agar memiliki manajemen pengelolaan yang modern tetapi berbasis pada kearifan lokal yang dimiliki oleh masyarakat setempat. Pengembangan pasar rakyat berbasis kearifan lokal tersebut nantinya akan memperhatikan bagaimana memberikan kenyamanan pengunjung pasar rakyat dengan berbagai produk-produk lokal yang unik dan bermutu. Fenomena tersebut menjadi hal yang menarik untuk 
dilakukan kajian mendalam tentang formulasi strategi pengembangan pasar daerah berbasis komoditas unggulan.

\section{KAJIAN PUSTAKA}

\subsection{Pasar Tradisional}

Terlepas dari sudah menjamurnya pasar modern, pasar tradisional masih memiliki beberapa keunggulan (Pramudyo dan Widyatmoyo 2008). Pertama adalah adanya kesempatan tawar menawar. Ada sentuhan humanis, sehingga mempunyai kedekatan personal maupun emosional. Keunggulan yang kedua adalah masalah kualitas. Pembeli yang teliti akan dengan mudah mendapatkannya dengan harga yang lebih murah jika dibandingkan dengan harga di pasar modern. Ketiga adalah pasar tradisional juga buka lebih pagi jika dibandingkan pasar tradisional. Keempat, yang menjadi keunggulan pasar tradisional adalah konsumen akan dengan cepat mengetahui adanya perubahan harga.

Sementara itu Mulyadi (2012) menyatakan bahwa pasar tradisional adalah cermin dari keberadaan kehidupan sosial di dalam satu wilayah tertentu. Pasar tradisional merupakan pusat kebudayaan, di mana segala macam ekspresi perilaku dan nilai yang melekat dalam masyarakat terekspresikan di dalamnya. Intensitas interaksi di dalam pasar tradisonal tidak kita temukan di pasar modern. Pasar sebagai pusat budaya terlihat ketika pasar tradisional tidak hanya menjadi ruang jual beli tetapi lebih dari itu pasar tadisional menjadi ruang ekspresi kesenian dan kebudayaan. Pasar tradisional memiliki peran penting dalam upaya membangun wawasan kebangsaan untuk ikut membangun suatu bentuk kebudayaan masa depan yang tak lepas dari akar tradisinya.

\subsection{Terminologi Pasar dari Perspektif Teoritis dan Regulatif}

Pasar di definisikan sebagai kumpulan penjual dan pembeli yang melakukan transaksi atas produk atau kelompok produk tertentu (Hakim, M.A. 2005) (1) terminologi lain dari pasar adalah sistem, institusi, prosedur, hubungan sosial dan infrastruktur di mana barang, jasa dan tenaga kerja ditransaksikan; dan (2) Menurut Kotler (1996) pasar terdiri dari semua pelanggan potensial yang memiliki kebutuhan atau keinginan tertentu, yang bersedia dan mampu berpartisipasi dalam pertukaran guna memuaskan atau memenuhi kebutuhan dan keinginan tersebut. Secara teoritis, definisi pasar terus berkembang dan direformulasi. Dewasa ini terminologi teoritis pasar lebih difokuskan pada aspek transaksi. Artinya, pasar tidak semata merujuk pada dimensi ruang atau tempat dan infrastruktur.

\subsection{Kualitas Produk Unggulan}

Kualitas produk adalah kemampuan keseluruhan ciri (atribut) produk atau jasa untuk memuaskan kebutuhan konsumen baik yang dinyatakan maupun yang tersirat. Dengan kata lain produk yang berkualitas diindikasikan oleh kemampuan produk untuk memenuhi atau melebihi harapan customer. Indikator kinerja kualitas produk yang baik juga dapat diamati pada pembelian berulang produk tersebut.

Kualitas produk memainkan peran penting untuk memenangkan persaingan. David A. Garvin menyusun formulasi kualitas produk dalam delapan dimensi sebagai berikut :

(1) Performance atau kinerja, merupakan dimensi kualitas yang berkaitan dengan karakteristik utama produk; (2) Features atau fitur, merujuk pada 
karakteristik pendukung atau pelengkap dari karakteristik utama produk; (3) Reliability atau kehandalan, yaitu dimensi kualitas yang berhubungan dengan kemungkinan sebuah produk dapat bekerja secara memuaskan pada waktu dan kondisi tertentu; (4) Conformance atau kesesuaian, dimensi ini merujuk pada kesesuaian kinerja dan kualitas produk dengan standar yang diinginkan; (5) Durability atau ketahanan, dimensi ini berkaitan dengan ketahanan suatu produk yang diukur dengan umur atau daya tahan suatu produk; (6) Serviceability, kemudahan layanan dikaitkan dengan kemudahan penanganan kerusakan produk; (7) Aesthetics atau keindahan, dimensi kualitas ini sangat erat terkait dengan tampilan, rasa maupun aroma suatu produk; dan (8) Perceived Quality, kesan kualitas suatu produk merupakan dimensi yang berkaitan dengan persepsi konsumen terhadap kualitas produk atau merek. Harga pada kondisi tertentu juga dapat menjadi elemen perceived quality.

\section{METODE PENELITIAN}

Berdasarkan tujuannya, jenis penelitian pengembangan pasar daerah berbasis komoditas lokal di Kabupaten Pasuruan ini adalah sebuah penelitian lapangan (Field Research) dengan menggunakan pendekatan Deskriptif Kuantitatif. Penelitian ini dilakukan di 14 pasar daerah yang berada di wilayah administrasi Kabupaten Pasuruan dan menyertakan 5 pasar desa.

Metode pengumpulan data dalam penelitian ini menggunakan 3 (tiga) macam teknik yaitu studi literatur, observasi lapang, dan wawancara, serta Forum Group Discussion (FGD). Sedangkan subyek penelitian ini meliputi para informan yaitu para pembeli, pedagang, orang dari Pemerintah Daerah Kabupaten Pasuruan, Dinas Perindustrian dan Perdagangan, Dinas Perikanan, Dinas Peternakan, Dinas Pertanian, dan UPT Pasar

Penelitian ini menggunakan metode analisis SWOT yaitu mengidentifikasi berbagai faktor antara Kekuatan (Strenght) dan Peluang (Opportunities), Kelemahan (Weakness) dan Ancaman / Resiko (Treats) secara sistematis untuk merumuskan strategi.

\section{HASIL DAN PEMBAHASAN}

\subsection{Faktor Determinan Pengembangan Produk Lokal Di Pasar Daerah}

Hasil kajian mengindikasikan bahwa customer segment yang dilayani oleh rantai pasar komoditas unggulan terdiri dari beberapa kategori, di antaranya konsumen akhir lokal, regional dan nasional serta konsumen dari kalangan industri ritel yang selanjutnya melakukan sejumlah fungsi pemasaran seperti standardisasi mutu, pelabelan dan pengemasan hingga produk sampai ke konsumen akhir.

Dari hasil turun lapang, dapat disimpulkan beberapa poin penting terkait produk unggulan di Kabupaten Pasuruan sebagai berikut: Temuan utama penelitian ini antara lain adalah:

1. Produk lokal unggulan Kabupaten Pasuruan belum menjadi ciri khas dan icon product pasar-pasar rakyat.

2. Customer segment yang dilayani oleh pasar komoditas dan pasar rakyat atau pasar daerah berbeda sehingga kebutuhan yang akan dipenuhi juga berbeda.

3. Produk agrokompleks lokal yang menjadi unggulan Kabupaten Pasuruan telah memiliki rantai pasok spesifik sehingga potensi memasarkan produk 
lokal secara langsung ke pasar rakyat hanya dapat dilakukan untuk surplus produksi atau produk dengan kualitas non premium

4. Determinan pengembangan aktivitas pemasaran produk lokal di pasar daerah Kabupaten Pasuruan hanya dimungkinkan bila pelaku pasar secara langsung mampu berintegrasi dalam aliran barang, uang dan informasi rantai pasok yang sudah tercipta sebelumnya

\subsection{Solusi Peningkatan Akses Pasar Daerah}

Solusi atas permasalahan akses pasar daerah untuk meningkatkan pemasaran produk lokal Kabupaten Pasuruan antara lain: (1) Menyediakan sarana parkir dan bongkar muat yang memadai; (2) Memberikan fasilitas penyimpanan khusus produk pertanian; (3) Meningkatkan kebersihan, sebab produk pertanian lokal unggulan dengan kualitas premium memerlukan penanganan pasca panen dan teknik penyimpanan yang baik; (4) Membangun fasilitas mechanical electric yang memadai dan memungkinkan pelaku pasar mengoperasikan mesin pendingin untuk mempertahankan kualitas produk; (5) Menata display produk unggulan agar lebih menarik; (6) Melengkapi fasilitas promosi produk yang informatif; (7) Meningkatkan kemampuan pelaku pasar untuk memahami prinsip-prinsip layanan berorientasi kepuasan konsumen; (8) Menerapkan sistem kalibrasi atau evaluasi tera secara berkala sebagai salah satu elemen dari implementasi dimensi reliabilitas atau kehandalan bertransaksi; dan (9) Kunci dari peningkatan akses pasar daerah atas pemasaran produk lokal unggulan Kabupaten Pasuruan adalah memperbesar kapasitas transaksi dan jumlah pengunjung. Semakin ramai dan semakin tinggi jumlah pengunjung ke pasar daerah, apalagi jika pengunjung berasal dari daerah lain, bukan hanya masyarakat sekitar kawasan maka akan semakin terbuka peluang memasarkan produk-produk kualitas premium, termasuk buah-buahan icon Pasuruan.

\subsubsection{Analisis SWOT Pengembangan Pasar Daerah}

Berdasarkan peta kondisi kesehatan pasar di Kabupaten Pasuruan sebagaimana dijelaskan di atas maka berikut ini dianalisis strategi pengembangan pasar melalui analisis SWOT. Analisis dimulai dengan mengidentifikasi faktor internal dan eksternal, yang akan diberikan bobot, rating, dan skor. Hasil analisis akan menghasilkan koordinat matrik SWOT yang mencerminkan strategi pengembangan pasar daerah di kabupaten Pasuruan.

Berdasarkan hasil analisis faktor internal sebagaimana disebutkan pada tabel 1, maka dapat diketahui beberapa faktor yang menjadi kekuatan (strength) dan kelemahan (weakness) pasar tradisional di Kabupaten Pasuruan. Faktor kekuatan yang paling menonjol adalah bahwa semua pasar yang menjadi sampel pada kajian ini terletak pada lokasi yang strategis. Hal ini berarti bahwa masyarakat cukup mudah menjangkau lokasi pasar, karena berdekatan dengan transportasi umum. Di samping itu lokasi pasar tidak terletak pada daerah yang rawan bencana, seperti banjir maupun longsor. Satu hal yang menjadi catatan pada faktor kekuatan ini adalah dimilikinya produk komoditas lokal yang menjadi andalan Jawa Timur dan bahkan Indonesia mangga dan durian. Kedua produk buah-buahan ini oleh para petani mangga dijual langsung ke luar daerah Pasuruan dan tidak melalui saluran pasar tradisional. Mekanisme pasar yang seperti ini wajar adanya, sebab permintaan mangga dan durian lebih banyak diminati oleh masyarakat di luar Pasuruan. 
Tabel 1. Analisis Faktor Internal (IFAS)

\begin{tabular}{|c|c|c|c|c|}
\hline No & Faktor Internal & Bobot & Rating & Skor \\
\hline A & Kekuatan (Strength) & & & \\
\hline 1. & $\begin{array}{l}\text { Lokasi pasar cukup strategis, tidak terletak pada } \\
\text { daerah rawan bencana. }\end{array}$ & 0.15 & 4 & 0.60 \\
\hline 2. & Semua pasar memiliki pengelola pasar. & 0.10 & 4 & 0.40 \\
\hline 3. & $\begin{array}{l}\text { Adanya regulasi yang mengatur pemberdayaan } \\
\text { pasar tradisional }\end{array}$ & 0.10 & 4 & 0.40 \\
\hline 4. & $\begin{array}{l}\text { Jumlah pasar yang cukup banyak, berpotensi } \\
\text { mendorong berputarnya roda perekonomian daerah }\end{array}$ & 0.10 & 4 & 0.40 \\
\hline 5. & $\begin{array}{l}\text { Semua pasar memiliki jumlah konsumen potensial } \\
\text { sangat besar }\end{array}$ & 0.05 & 3 & 0.15 \\
\hline 6. & $\begin{array}{l}\text { Produk mangga dan durian menjadi unggulan utama } \\
\text { yang dihasilkan dari kabupaten Pasuruan }\end{array}$ & 0.10 & 3 & 0.30 \\
\hline & Sub total & 0.60 & & 2.25 \\
\hline
\end{tabular}

\section{B Kelemahan (Weakness)}

1. Banyaknya jumlah pasar belum didukung dengan kondisi bangunan yang memadai (konstruksi, penataan area belum sesuai jenis komoditi basah dan kering, unggas hidup dan pemotongannya)

2. Sanitasi belum memadai (drainase tidak berfungsi secara baik, kondisi kamar mandi dan toilet, air bersih belum semua tersedia, desinfeksi pasar belum dilakukan, belum bebas dari vector/bintang penular penyakit seperti lalat, kecoa, tikus)

2. Belum tersedia fasilitas keamanan seperti hidran air untuk pemadam kebakaran dengan jumlah cukup

$\begin{array}{lll}0.10 & 1 & 0.10\end{array}$

3. Sikap dan perilaku pedagang kurang mendukung terciptanya lingkungan hidup bersih dan sehat

4. Belum memiliki pusat informasi yang menjadi media komunikasi pemda dengan pedagang pasar. Misal untuk sosialisasi PHBS (Pola Hidup Bersih dan Sehat)

5. Belum semua pasar memiliki fasilitas ibadah untuk meningkatkan ketaqwaan pedagang kepada Allah SWT

$\begin{array}{lll}0.03 & 2 & 0.06\end{array}$

6. Jumlah karyawan pengelola pasar relative sedikit, tiap pasar rata-rata hanya 2 orang

$\begin{array}{lll}0.02 & 2 & 0.04\end{array}$

7. Produk yang dijual di pasar tradisional rata-rata berasal dari luar Pasuruan

$\begin{array}{lll}0.03 & 1 & 0.03\end{array}$

\begin{tabular}{lcc}
\hline Sub total & 0.40 & 0.57 \\
\hline Total & 1 & 1.68 \\
\hline
\end{tabular}

Sumber: Hasil Pengolahan Data 
Sedangkan untuk faktor kelemahan (weakness) yang paling menonjol yaitu keberadaan sanitasi yang belum memadai (drainase tidak berfungsi secara baik, kondisi kamar mandi dan toilet, air bersih belum semua tersedia, desinfeksi pasar belum dilakukan, belum bebas dari vector/bintang penular penyakit seperti lalat, kecoak, tikus). Kondisi drainase yang tidak berfungsi baik ini juga tidak bisa dipisahkan dengan sikap (attitude) para pedagang yang membuang sampah sembarangan. Kepemilikan pusat informasi sangat mendesak untuk dilakukan guna menyampaikan informasi penting dari Pemda sekaligus sebagai media untuk mendidik attitude pedagang dan pengunjung pasar. Pemisahan sampah basah dan kering akan menunjang terwujudnya kebersihan dan meminimkan munculnya binatang penular penyakit seperti lalat dan tikus. Desinfeksi pasar perlu dilakukan secara periodik untuk membasmi binatang penular penyakit. Untuk itu diperlukan adanya kerja sama dengan dinas kesehatan daerah setempat.

Di samping faktor internal, juga dilakukan analisis terhadap faktor eksternal. Selengkapnya dapat dilihat pada tabel berikut.

Tabel 2. Analisis Faktor Eksternal (EFAS)

\begin{tabular}{|c|c|c|c|c|}
\hline No & $\begin{aligned} \text { Faktor Internal } \\
\end{aligned}$ & Bobot & Rating & Skor \\
\hline A & Peluang (Opportunity) & & & \\
\hline 1. & $\begin{array}{l}\text { Pemerintah daerah memiliki peluang untuk } \\
\text { meningkatkan pendapatan dari sector pajak dan } \\
\text { sewa kios }\end{array}$ & 0.30 & 4 & 1.20 \\
\hline 2. & $\begin{array}{l}\text { Banyaknya produk hasil pertanian berpotensi } \\
\text { menarik perhatian investor untuk menanamkan } \\
\text { modalnya di Kabupaten Pasuruan }\end{array}$ & 0.15 & 3 & 0.45 \\
\hline 3. & $\begin{array}{l}\text { Upaya pemberdayaan UKM yang menghasilkan } \\
\text { produk olahan dapat mengatasi hasil panen yang } \\
\text { berlimpah }\end{array}$ & 0.10 & 3 & 0.30 \\
\hline 4. & $\begin{array}{l}\text { Pembentukan saluran distribusi seperti agen, } \\
\text { supplier, pengecer, dan lain-lain berpotensi dapat } \\
\text { menyerap tenaga kerja untuk mengatasi } \\
\text { pengangguran }\end{array}$ & 0.05 & 3 & 0.15 \\
\hline & Sub total & 0.60 & & 2.10 \\
\hline B & Ancaman (Threats) & & & \\
\hline 1. & $\begin{array}{l}\text { Bila kondisi bangunan dan sanitasi tidak segera } \\
\text { diperbaiki, maka berpotensi menjadi sumber } \\
\text { penyakit }\end{array}$ & 0.15 & 1 & 0.15 \\
\hline 2. & $\begin{array}{l}\text { Attitude para pedagang yang tidak mendukung } \\
\text { terciptanya lingkungan bersih dan sehat juga } \\
\text { berpotensi menimbulkan penyakit }\end{array}$ & 0.15 & 1 & 0.15 \\
\hline 3. & $\begin{array}{l}\text { Pengetahuan dan Ketrampilan pedagang perlu } \\
\text { ditingkatkan agar tidak kalah dengan pasar } \\
\text { modern }\end{array}$ & 0.05 & 2 & 0.10 \\
\hline 4. & $\begin{array}{l}\text { Penerapan regulasi pasar modern perlu } \\
\text { ditegakkan untuk melindungi pasar tradisional }\end{array}$ & 0.05 & 1 & 0.05 \\
\hline & Sub total & 0.40 & & 0.45 \\
\hline & Total & 1 & & 1.65 \\
\hline
\end{tabular}


Berdasarkan hasil analisis eksternal tersebut dapat diketahui adanya beberapa faktor yang menjadi peluang (opportunity) dan sekaligus menjadi ancaman (threats) bagi keberadaan pasar tradisional di Kabupaten Pasuruan. Di antara beberapa komponen faktor peluang, yang paling menonjol adalah adanya peluang Pemerintah Daerah untuk meningkatkan pendapatan asli daerah (PAD) dari sektor pajak dan sewa kios. Jika pemerintah menyediakan kios yang layak bagi pedagang, sebenarnya merupakan investasi yang akan menghasilkan pendapatan untuk jangka panjang. Di samping itu pemerintah daerah juga memperoleh masukan dari sektor pajak, baik pajak penjualan maupun parkir kendaraan.

Untuk faktor ancaman (threats) yang paling menonjol adalah faktor kondisi bangunan, sanitasi dan attitude para pedagang. Ketiga faktor ini saling berkaitan, sebab kondisi bangunan dan sanitasi yang bagus tanpa dibarengi perubahan attitude pedagang yang bagus, maka tidak akan berhasil. Oleh sebab itu penambahan fasilitas pasar seperti meja, penerangan, tempat sampah, toilet, sanitasi, dll tersebut perlu mempertimbangkan faktor pemeliharaan dan perubahan attitude pedagang.

Setelah dilakukan analisis IFAS dan EFAS, maka langkah berikutnya adalah membuat matrik SWOT yang merupakan kombinasi dari komponen kekuatan, kelemahan, peluang dan ancaman. Untuk lebih jelasnya dapat dilihat pada diagram berikut:

\begin{tabular}{lcc}
\hline $\begin{array}{l}\text { IFAS } / \\
\text { EFAS }\end{array}$ & $\begin{array}{c}\text { STRENGTH } \\
(\text { Skor IFAS }>\text { 2) }\end{array}$ & $\begin{array}{c}\text { WEAKNESSES } \\
(\text { Skor IFAS } \leq 2)\end{array}$ \\
\hline $\begin{array}{l}\text { OPPORTUNITY } \\
(\text { Skor EFAS }>2)\end{array}$ & Strategi $\mathrm{S}-\mathrm{O}$ & Strategi $\mathrm{W}-\mathrm{O}$ \\
\hline $\begin{array}{l}\text { THREATS } \\
(\text { Skor EFAS } \leq 2)\end{array}$ & Strategi $\mathrm{S}-\mathrm{T}$ & Strategi W $-\mathrm{T}$ \\
\hline
\end{tabular}

\section{Gambar 3. Matrik SWOT}

Berdasarkan hasil analisis IFAS dan EFAS sebagaimana terdapat pada tabel 1 dan 2 di atas maka dapat diketahui bahwa skor IFAS adalah 1.68, sedangkan skor EFAS adalah 1.65. Dengan demikian strategi pengembangan pasar daerah yang sesuai untuk kabupaten Pasuruan adalah menggunakan kuadran 4 yaitu strategi $\mathrm{W}-$ $\mathrm{T}$ (Weakness - Threats). Hal ini berarti bahwa untuk mengembangkan pasar daerah dapat dilakukan dengan memperkecil faktor kelemahan guna menghindari adanya berbagai ancaman. Berikut adalah pengembangan pasar daerah di Kabupaten Pasuruan berbasis strategi W-T (Weakness - Threats).

Berdasarkan keterangan pada tabel 3, maka dapat diketahui bahwa beberapa perubahan perlu segera dilakukan oleh Pemerintah Daerah Kabupaten Pasuruan untuk menuju terbentuknya pasar daerah yang sehat. Strategi yang direkomendasikan untuk melakukan perubahan tersebut adalah melalui strategi $\mathrm{W}-\mathrm{T}$ (Weakness Threats) artinya upaya mengembangkan pasar daerah di Kabupaten Pasuruan dapat dilakukan dengan memperkecil faktor kelemahan guna menghindari adanya berbagai ancaman. 
Tabel 3. Strategi W - T untuk Pengembangan Pasar Daerah di Kabupaten Pasuruan

\begin{tabular}{|c|c|c|}
\hline No & Kelemahan (Weakness) & $\begin{array}{c}\text { Ancaman Risiko \& Strategi } \\
\text { Pengembangan } \\
\end{array}$ \\
\hline 1. & $\begin{array}{l}\text { Banyaknya jumlah pasar belum } \\
\text { didukung dengan kondisi bangunan yang } \\
\text { memadai (konstruksi, penataan area } \\
\text { belum sesuai jenis komoditi basah dan } \\
\text { kering, unggas hidup dan } \\
\text { pemotonganna) }\end{array}$ & $\begin{array}{l}\text { Untuk mengurangi risiko munculnya } \\
\text { wabah penyakit di lingkungan pasar, } \\
\text { maka perlu dilakukan perbaikan } \\
\text { bangunan pasar dan penataan area } \\
\text { komoditi }\end{array}$ \\
\hline 2. & $\begin{array}{l}\text { Sanitasi belum memadai (drainase tidak } \\
\text { berfungsi secara baik, kondisi kamar } \\
\text { mandi dan toilet, air bersih belum semua } \\
\text { tersedia, desinfeksi pasar belum } \\
\text { dilakukan, belum bebas dari } \\
\text { vector/binatang penular penyakit seperti } \\
\text { lalat, kecoa, tikus) }\end{array}$ & $\begin{array}{l}\text { Untuk mengurangi risiko munculnya } \\
\text { binatang penular penyakit seperti tikus, } \\
\text { kecoa, lalat maka perlu perbaikan } \\
\text { drainase, pemisahan toilet laki dan } \\
\text { perempuan, penyediaan air bersih yang } \\
\text { mengalir, dan melakukan disinfeksi } \\
\text { minimal setahun sekali. }\end{array}$ \\
\hline 3. & $\begin{array}{l}\text { Belum tersedia fasilitas keamanan seperti } \\
\text { hidran air untuk pemadam kebakaran } \\
\text { dengan jumlah yang cukup }\end{array}$ & $\begin{array}{l}\text { Untuk mencegah resiko terjadinya } \\
\text { kebakaran, perlu menyediakan sarana } \\
\text { hidran air yang cukup }\end{array}$ \\
\hline 4. & $\begin{array}{l}\text { Sikap dan perilaku pedagang kurang } \\
\text { mendukung terciptanya lingkungan } \\
\text { hidup bersih dan sehat }\end{array}$ & $\begin{array}{l}\text { Untuk mencegah risiko munculnya } \\
\text { berbagai penyakit dan gangguan } \\
\text { kesehatan lainnya, maka perlu upaya } \\
\text { sosialisasi pola hidup bersih dan sehat } \\
\text { melalui pusat informasi yang disediakan } \\
\text { oleh pengelola pasar. }\end{array}$ \\
\hline 5. & $\begin{array}{l}\text { Belum memiliki pusat informasi yang } \\
\text { menjadi media komunikasi pemda } \\
\text { dengan pedagang pasar. Misal untuk } \\
\text { sosialisasi PHBS (Pola Hidup Bersih dan } \\
\text { Sehat) }\end{array}$ & $\begin{array}{l}\text { Untuk mempermudah penyampaian } \\
\text { informasi PHBS, pajak, kebersihan, dan } \\
\text { lain-lain informasi dari PEMDA, maka } \\
\text { perlu mengupayakan pengeras suara } \\
\text { untuk media sosialisasi program } \\
\text { pemerintah. }\end{array}$ \\
\hline 6. & $\begin{array}{l}\text { Belum semua pasar memiliki fasilitas } \\
\text { ibadah untuk meningkatkan ketakwaan } \\
\text { pedagang kepada Tuhan Yang Maha } \\
\text { Kuasa }\end{array}$ & $\begin{array}{l}\text { Guna meningkatkan ketakwaan para } \\
\text { pedagang kepada Tuhan Yang Maha } \\
\text { Kuasa, perlu direncanakan pembangunan } \\
\text { mushola }\end{array}$ \\
\hline
\end{tabular}

Sumber: Hasil Pengolahan Data

\subsection{Strategi Pengembangan Pasar Daerah Kabupaten Pasuruan}

Hasil penelitian menunjukkan bahwa keberadaan pasar tradisional belum dimanfaatkan secara sinergis oleh para pengelola dan para pedagang pasar tradisional. Terjadinya pergeseran tren berbelanja di antara berbagai segmen, dari pasar tradisional yang dikelola secara konvensional ke pasar modern yang dikelola secara profesional. Padahal, adanya daya tarik pasar tradisional sebagai bagian dari objek wisata yang didukung budaya lokal, seharusnya dapat dipandang sebagai peluang yang menjanjikan sepanjang mampu dikelola secara sinergis semua potensi yang dimiliki dan pada gilirannya dapat meningkatkan kesejahteraan masyarakat.

Pengembangan pasar tradisional secara bijak dengan tidak meninggalkan kearifan lokal, sesungguhnya semakin strategis posisinya dalam memperkokoh 
perekonomian karena dapat menciptakan lapangan berusaha dan lapangan pekerjaan dengan melibatkan hajat hidup masyarakat di sekitarnya yang lebih banyak. Hasil kaji lapang menunjukkan bahwa hampir 60 persen masyarakat Kabupaten Pasuruan tetap mengandalkan pasar tradisional, di sana jumlah pekerja kelas menengah ke bawah terserap cukup banyak. Dengan demikian, jika pasar tradisional tidak diberdayakan atau direvitalisasi bahkan terkesan dibiarkan mati karena hadirnya pasar modern dan hypermarket, maka sudah dapat dipastikan potensi pengangguran akan terus bertambah dan pada gilirannya akan membebankan pemerintah.

Beberapa kelemahan yang ada di pasar tradisional ada antara lain :

1. Lemahnya manajemen pasar, tidak ada visi dan misi. Seperti pernah diteliti oleh Bart et al (2001), yang mengatakan bahwa pernyataan misi suatu organisasi merupakan titik awal dari inisiatif perencanaan strategi utama. Selain itu, pernyataan misi yang tepat akan memberikan pengaruh positif terhadap pencapaian kinerja organisasi Falsley (1989); Maslen dan Platts (1997); Kakbedse dan Kakabadse (2001); Analoui dan Karami (2002); dan Bart et al. (2001); serta Darbi (2012). Di samping apresiasi yang rendah terhadap pernyataan visi dan misi.

2. Pemahaman yang rendah terhadap pengembangan sistem pemasaran, terbatasnya ruang pada pelataran yang sempit, barang dagangan tidak tertata rapi, lingkungan yang kurang bersih, kurangnya tempat penampungan sampah, dan belum tersedianya fasilitas infrastruktur pasar berupa pergudangan.

3. Rendahnya pengawasan kualitas terhadap barang yang dijual, dapat menjadikan daya saing untuk menarik pelanggan sangat lemah dibandingkan pasar modern.

Namun demikian, masih terdapat kekuatan yang maha dahsyat yang dimiliki oleh pasar tradisional antara lain:

1. Keberadaan pasar tradisional sebagai bagian dari objek wisata pasar tradisional

2. Harga yang ditawarkan lebih murah

3. Kesegaran produk yang diperdagangkan

4. Kekerabatan antara penjual dan pembeli

5. Kesederhanaan proses pembayaran

Di antara ancaman yang ada, ternyata bila lebih cermat diperhatikan masih terdapat peluang tersembunyi. Dalam hal ini diperlukan analisis terhadap lingkungan baik pada aspek eksternal maupun internal. Perumusan strategi berdasarkan analisis lingkungan eksternal dan internal pernah dilakukan oleh Ahmed dan Almarri (2006), Evans dan Wright (2009), Helms dan Nixon (2010), dan Antony (2012). Dengan perumusan dan penerapan strategi bisnis yang tepat akan menyebabkan keberadaan pasar tradisional akan tetap eksis dalam menjaga kestabilan perekonomian daerah, terutama di tengah menjamurnya pasar modern.

Pada dasarnya pasar tradisional bisa dikelola dengan manajemen sederhana baik itu orangnya atau teknologinya. Manusia pengelola perlu diatur mekanisme perekrutannya. Sistem manajemen pengelolaan dan keuangan dibuat sebersih mungkin agar selalu bisa diawasi oleh pedagang dan pembeli. Sedang teknologinya secara sederhana dapat menggunakan teknologi konstruksi yang cukup untuk memberikan kekokohan bangunan, sanitasi yang baik, lantai kering dan tidak licin, sirkulasi udara yang baik, pencahayaan yang cukup, dan jalur antar blok yang 
membuat pembeli mudah bergerak dari satu blok ke blok lain.

Pasar tradisional juga bisa mengelola papan iklan pada bagian luar pasarnya untuk mempromosikan harga tertentu yang lagi didiskon atau sebuah produk baru sedang melakukan promosi. Promosi ini bisa melalui papan pengumuman atau menggunakan teknologi pengeras suara. Selain itu, banyak program tertentu baik itu bersumber dari pemerintah desa atau gapoktan untuk menumpang dalam bentuk pengumuman atau sosialisasi melalui pasar tradisional.

Untuk meningkatkan rasa kepemilikan badan hukum pasar tradisional perlu diubah. Pasar tradisional umumnya adalah milik pemerintah daerah. Perlu didorong untuk pengelolaan dengan menggunakan model bisnis tertentu sehingga pasar itu juga dimiliki oleh pedagang yang ada di pasar. Strateginya dengan membentuk koperasi pedagang, lalu pedagang diberi saham dalam pengelolaan pasar tradisional tersebut.

\section{KESIMPULAN DAN SARAN}

\subsection{Kesimpulan}

1) Kondisi eksisting pasar daerah dan pasar desa yang di kaji, secara garis besar jika dikategorisasikan berdasarkan orbitrasi jalan, luasan dan daya tampung, sebagian besar terkategorikan dalam pasar tipe A. Namun, jika dikaji berdasarkan ketersediaan fasilitas umum di pasar daerah Kabupaten Pasuruan sebagian besar memerlukan adanya revitalisasi baik pasar yang terkategori dalam tipe A maupun tipe B, dan C.

2) Manajemen pasar daerah dan pasar desa di Kabupaten Pasuruan masih memiliki pemahaman yang rendah terhadap pengembangan sistem pemasaran, terbatasnya ruang pada pelataran yang sempit, barang dagangan tidak tertata rapi, lingkungan yang kurang bersih, kurangnya tempat penampungan sampah, dan belum tersedianya fasilitas infrastruktur pasar berupa pergudangan Rendahnya pengawasan kualitas terhadap barang yang dijual, dapat menjadikan daya saing untuk menarik pelanggan sangat lemah dibandingkan pasar modern.

3) Produk lokal Kabupaten Pasuruan merupakan totalitas produk berbasis komoditas agrokompleks yang mencakup produk pertanian baik tanaman pangan maupun hortikultura, tanaman perkebunan, peternakan, perikanan, dan agroindustri.

4) Produk pertanian lokal unggulan Kabupaten Pasuruan adalah mangga Gadung klon 21, apel dan durian. Mangga dan durian merupakan produk lokal Pasuruan yang sebagian masih dipasarkan lokal melalui event festival mangga dan durian yang digelar Pemerintah Kabupaten Pasuruan sesuai musim di pasar wisata Cheng Hoo. Dewasa ini agrowisata telah menjadi best practice penjualan produk unggulan kualitas premium. Segmen pasar yang disasar sebagai target pemasaran sudah jelas sebab posisi produk telah mantap baik dari aspek kualitas maupun kontinyuitas jumlah pasokan. Baik mangga, durian maupun apel Pasuruan belum menjadi ciri komoditas di pasar-pasar rakyat atau pasar daerah.

5) Praktik pemasaran produk pertanian semacam ini telah menjadi pola umum. Itulah sebabnya rantai pasar produk pertanian panjang. Nilai tambah yang diciptakan sepanjang simpul rantai pasok juga tinggi. Pada gilirannya, 
sampai ke tangan konsumen akhir, margin pemasaran, dan disparitas harga jual antara harga produsen dan konsumen cukup besar.

6) Hasil analisis faktor internal maka dapat diketahui beberapa faktor yang menjadi kekuatan (strength) dan kelemahan (weakness) pasar tradisional di Kabupaten Pasuruan. Faktor kekuatan yang paling menonjol adalah bahwa semua pasar yang menjadi sampel pada kajian ini terletak pada lokasi yang strategis. Sedangkan untuk faktor kelemahan (weakness) yang paling menonjol yaitu keberadaan sanitasi yang belum memadai (drainase tidak berfungsi secara baik, kondisi kamar mandi dan toilet, air bersih belum semua tersedia, desinfeksi pasar belum dilakukan, belum bebas dari vector/bintang penular penyakit seperti lalat, kecoa, tikus). Kondisi drainase yang tidak berfungsi baik ini juga tidak bisa dipisahkan dengan sikap (attitude) para pedagang yang membuang sampah sembarangan

\subsection{Saran}

1) Pemerintah Daerah Kabupaten Pasuruan perlu melakukan revitalisasi pasar tradisional yaitu perbaikan (renovasi) fisik bangunan pasar dan disertai dengan pembangunan kelembagaan (institutional building) seperti mengembangkan organisasi (organizational development) pengelola dan pembina pasar tradisional, termasuk di dalamnya pengembangan sistem manajemen pasar beserta sumber daya manusia (SDM) yang terlibat serta pedagang pasar.

2) Untuk meningkatkan pemasaran produk lokal Kabupaten Pasuruan antara lain: menyediakan sarana parkir dan bongkar muat yang memadai, memberikan fasilitas penyimpanan khusus produk pertanian, meningkatkan kebersihan, membangun fasilitas mechanical electric, menata display produk unggulan agar lebih menarik, melengkapi fasilitas promosi produk yang informatif, meningkatkan kemampuan pelaku pasar, menerapkan sistem kalibrasi atau evaluasi tera secara berkala.

\section{DAFTAR PUSTAKA}

Akung, A.M., 24 November 2011,'Menjaga Pasar Tradisional',< https://budisansblog.blogspot.co.id/2011/11/menjaga-pasar-tradisional.html?>, diakses 4 Mei 2017

Arsyad, Lincolin. 2004. Ekonomi Pembangunan, Edisi 4. Yogyakarta: STIE YKPN.

Deil, S.A.F., 13 Juni 2014,'Indomaret vs Alfamart, Pertarungan Sengit Raksasa Ritel Indonesia', < http://bisnis.liputan6.com/read/2062826/indomaret-vs-alfamartpertarungan-sengit-raksasa-ritel-indonesia>, diakses 5 Mei 2017

Hakim, M.A., 2005, Menguasai Pasar Mengeruk Untung, Krisna Persada, Renaisan, Jakarta

Https://id.wikipedia.org/wiki/Pasar

Http://www.hukumonline.com/klinik/detail/lt4fceff7b57828/ketentuan-tentangjarak-minimarket-dari-pasar-tradisional, Diakses 2 April 2017

Indroyono, Puthut. 2013. "Revitalisasi Pengelolaan Pasar Rakyat Berbasis Ekonomi Kerakyatan". Yogyakarta: Academic article presented in Center for Economic Democracy Studies. Universitas Gadjah Mada. 
Mubyarto, 1989, Pengantar Ekonomi Pertanian, LP3ES, Jakarta dalam Agustian, A. dan A. Setiajie, I., 2008, Dinamika Pembangunan Pertanian dan Perdesaan: Tantangan dan Peluang bagi Peningkatan Kesejahteraan Petani, Pusat Analisis Sosial Ekonomi dan Kebijakan Pertanian, IPB.

Nabila, M., 3 Maret 2016,'Hypermarket Fokus Tambah Gerai di Luar Jawa', http://industri.bisnis.com/read/20160303/12/524677/hypermarket-fokustambah-gerai-di-luar-jawa, diakses 9 Mei 2017

Kertasasmita, Ginanjar. 1996. Pembangunan untuk Rakyat Memadukan Pertumbuhan dan Pemerataan. Jakarta: Pustaka Cidesindo.

Kupita dan Bintoro, 2012, Implementasi Kebijakan Zonasi Pasar Tradisional dan Pasar Modern (Studi di Kabupaten Purbalingga), Jurnal Dinamika Hukum, Vol 12. No 1 Januari 2012

Kusumawardhani, A., 8 Februari 2017, 'Ekspansi Gerai: Peritel Modern Keluhkan Soal Perizinan', <http://industri.bisnis.com/read/20170208/12/627062/ekspansigerai-peritel-modern-keluhkan-soal-perizinan>, diakses 10 Mei 2017

Peraturan Menteri Perdagangan Nomor 70 Tahun 2003 tentang "Penataan dan Pembinaan Pasar Tradisional, Pusat Pembelanjaan, dan Toko Modern". http://pelayanan. jakarta. go. id/download/regulasi/peraturan-menteriperdagangan- nomor-70-m-dag-per-12-2013-tentang-pedoman-penataan- danpembinaan-pasar-tradisional-pusat-perbelanjaan-dan- toko-modern. pdf, Diakses 2 April 2017

Peraturan Menteri Perdagangan Republik Indonesia Nomor: 53/M- Dag/Per/12/2008 tentang Pedoman Penataan dan Pembinaan Pasar Tradisional, Pusat Perbelanjaan, dan Toko Modern, http:/ /pasarjaya. co. id/_assets/files/about/

Peraturan_Menteri_Dalam_Negeri_Nomor_53_Tahun_2008. pdf, Diakses 2 April 2017

Peraturan Presiden Nomor 112 Tahun 2007 tentang Penataan dan Pembinaan Pasar Tradisional, Pusat Perbelanjaan, dan Toko Modern, hukum.unsrat.ac.id/pres/perpres_112_2007, diakses 2 April 2017

Poesoro, A., 2007,'Pasar Tradisional di Era Persaingan Global' dalam SMERU Newsletter No 22. April-Juni 2007, < www.smeru.or.id/sites/default/files/publication/news22.pdf >, diakses 5 Mei 2017

Rafiq, Aunur. 2014. Pertumbuhan Ekonomi dan Kemiskinan. Jakarta: Republika.

Suharto, Edi. 2010. Analisis Kebijakan Publik: Panduan Praktis Mengkaji Masalah dan Kebijakan Sosial..Jakarta: Kencana

Wiangga, L.S., 'Laju Saham 8 Mei 2017,' Berikut Bahasan Aksi Emiten', < http://market.bisnis.com/saham-sekuritas>, diakses 10 Mei 2017

Winarno, Budi. 2012.Kebijakan Publik: Teori, Proses, dan Studi Kasus.Yogyakarta: PT. Buku Seru 